\title{
A case of normoprolactinemic galactorrhea following aneurysmal subarachnoid hemorrhage
}

\author{
Edilfavia Mae Uy*, Kamyar Asadipooya \\ Division of Endocrinology and Molecular Medicine, Department of Medicine, University of Kentucky, Lexington, KY, USA
}

Received: November 5, 2018

Accepted: November 30, 2018 Online Published: December 7, 2018

DOI: $10.5430 /$ crim.v6n1p8

URL: https://doi.org/10.5430/crim.v6n1p8

\begin{abstract}
Galactorrhea is most commonly associated with elevated levels of prolactin; however, it does happen in individuals whose prolactin level is within normal range. Galactorrhea has been reported after neurosurgical procedures, cranial trauma or cerebral hemorrhage affecting the hypothalamus, pituitary or pituitary stalk, but these were associated with elevated levels of prolactin. In our knowledge, there has not been a case reported wherein a patient developed normoprolactinemic galactorrhea after an aneurysmal subarachnoid hemorrhage. The etiology and pathophysiology of normoprolactinemic galactorrhea have not been distinctly defined making this entity a diagnostic and therapeutic challenge for physicians.
\end{abstract}

Key Words: Galactorrhea, Prolactin

\section{INTRODUCTION}

Galactorrhea is defined as presence of spontaneous milky nipple discharge at any time in men and women with no recent history of pregnancy or lactation. This is a relatively common problem that occurs in $20 \%-25 \%$ percent of women. ${ }^{[1]}$ It may also happen in postmenopausal women and men. The female breast is primarily prepared for lactation by the effects of steroids (estrogen, progesterone and glucocorticoid), growth hormone, insulin, thyroid hormone and prolactin. Prolactin also has an essential role not only in breast development but in physiologic and pathologic galactorrhea. ${ }^{[2]}$ Galactorrhea results from the integrated interaction between neuroendocrine mechanisms which involve hypothalamus, pituitary, gonads, sex hormones, prolactin and breast tissue therefore, understanding the neuroendocrine regulation of prolactin may highlight cues to diagnose the etiology in order to treat galactorrhea appropriately. Prolactin is mainly secreted by lactotrophic cells in the anterior pituitary gland.
Chorion, decidual tissue and endometrial tissue can also synthesize prolactin. ${ }^{[2,3]}$ Excess prolactin secretion due to hypothalamic or pituitary lesion has been reported as the main reason for galactorrhea many years ago; however, it was difficult to measure prolactin ${ }^{[4]}$ in the past until it was successfully measured in $1970 .{ }^{[5]}$ The etiology of galactorrhea could be from a physiologic condition or from a pathologic cause (see Table 1). The mechanism of galactorrhea most commonly involves an increase in prolactin secretion or decrease in prolactin inhibiting factor (dopamine). Although prolactin plays a main role in galactorrhea, normoprolactinemic galactorrhea does exists. It is usually a benign condition that does not need further evaluation like hormonal assays and imaging. It also does not warrant long-term treatment unless the galactorrhea is troublesome or is associated with infertility and/or menstrual irregularities..$^{[1,2]}$ Nevertheless, investigating the underlying cause of normoprolactinemic galactorrhea may help us in instituting a better diagnostic

\footnotetext{
*Correspondence: Edilfavia Mae Uy; Email: Edilfaviamae.Uy@uky.edu; Address: Division of Endocrinology and Molecular Medicine, Department of Medicine, University of Kentucky, Lexington, KY, USA.
} 
and treatment approach.

\section{CASE REPORT}

A 51 year-old woman with a past medical history of hypertension presented to the Endocrinology clinic with galactorrhea for 2 years. Galactorrhea started 3 weeks after surgical intervention of aneurysmal subarachnoid hemorrhage which was done in 2016. She has a history of dysfunctional uterine bleeding that started in 2015 and had endometrial ablation in 2017 with subsequent amenorrhea post ablation. Home medications consist of losartan/ hydrochlorothiazide and multivitamin. She is a housewife with no history of smoking, alcohol or drug consumption. Work up done showed TSH of $0.841 \mathrm{uIU} / \mathrm{ml}$, Free T4 of $1.04 \mathrm{ng} / \mathrm{dl}$, FSH of $6.0 \mathrm{mIU} / \mathrm{ml}$, LH of $11.3 \mathrm{mIU} / \mathrm{ml}$, estradiol of $150.8 \mathrm{pg} / \mathrm{ml}$, IGF-1 of 183 $\mathrm{ng} / \mathrm{ml}$, cortisol of $8.24 \mathrm{ug} / \mathrm{dl}$ and prolactin of $15.1 \mathrm{ng} / \mathrm{ml}$. Repeat thyroid function was normal (TSH $0.47 \mathrm{uIU} / \mathrm{ml}$ and free $\mathrm{T} 4$ of $1.3 \mathrm{ng} / \mathrm{dl}$ ) and repeat prolactin level was still within normal range at $12.8 \mathrm{ng} / \mathrm{ml}$. Prolactin dilution was also done and was normal. Laboratory work up since 2016 were also reviewed and no abnormalities were noted. She has had normoprolactinemic galactorrhea for 2 years with no definite etiology. CT of the brain reported pituitary gland unremarkable and bilateral mammography was normal. The patient has refused medical therapy and her galactorrhea has persisted since 2016 but this has slowly improved over time.

\section{Discussion AND REVIEW OF Litera- TURE}

The word 'galactorrhea' comes from the Greek word 'galaktos' meaning 'milk' and 'rhein' means 'to flow' ${ }^{[6]}$ Reproductive hormones are important in the development of breast in puberty and in lactation. Estrogen promotes the growth of the mammary gland and ducts and have a direct stimulatory effect on the pituitary lactotrophs and prolactin secretion. ${ }^{[2,6]}$ Progesterone acts in conjunction with estrogen to regulate breast development and stimulates the development of milkproducing cells. Prolactin released from the anterior pituitary gland stimulates milk production. Oxytocin released from the posterior pituitary in response to suckling causes milk ejection from the lactating breast. In galactorrhea, milk production occurs spontaneously and it is not associated with pregnancy or lactation. ${ }^{[6]}$

Galactorrhea has been found to be caused by different etiologies (see Table 1). When galactorrhea is accompanied by amenorrhea, it is usually caused by hyperprolactinemia. However, when a patient has normal ovulatory menstrual cycle and galactorrhea, prolactin levels are usually normal. ${ }^{[2]}$

Published by Sciedu Press

\subsection{Etiology of normoprolactinemic galactorrhea}

The etiology of normoprolactinemic galactorrhea is usually idiopathic; however, it has been documented in different situations (see Table 2). Galactorrhea has been reported with traumatic brain injury and subdural hematoma, but these were associated with high prolactin level and galactorrhea resolved with dopamine agonist. ${ }^{[7]}$ Spontaneous intracranial hypotension can also lead to both hyperprolactinemic and normoprolactinemic galactorrhea. ${ }^{[8]}$ It is thought that intracranial hypotension causes brain sagging which can distort the pituitary stalk or cause pituitary enlargement. These two findings were reported in patients with normal prolactin levels. ${ }^{[8]}$ Low cerebrospinal fluid pressure that may be seen after head trauma or cranial surgery can also cause pituitary stalk compression that was associated with galactorrhea in a patient with normal basal prolactin level. ${ }^{[9]}$ In our patient, the development of normoprolactinemic galactorrhea after surgical intervention for aneurysmal brain hemorrhage could be possibly from the hemorrhage or decompression after surgical intervention leading to intracranial hypotension or low cerebrospinal fluid pressure.

\subsection{Pathophysiology of normoprolactinemic galactor- rhea}

The pathophysiology of normoprolactinemic galactorrhea is not completely understood. Multiple factors including prolactin (probably the most important factor), pituitary-gonadal axis, thyrotropin-releasing hormone, growth hormone and dopamine product receptor contribute to the development of normoprolactinemic galactorrhea. Reviewing the role of each piece of this puzzle may give us an insight into the process of events leading to the development of normoprolactinemic galactorrhea and thus enabling us to formulate a suitable treatment approach.

Normal serum prolactin levels in the presence of galactorrhea could be related to variable molecular heterogeneity of this peptide hormone. A variant of prolactin that has high bioactivity especially on mammary tissue (as evidenced by galactorrhea) but lower immunoreactivity (poor recognition by immunoassay for prolactin) may account for galactorrhea with normal prolactin levels. ${ }^{[13,16,29]}$

Intermittent hypersecretion of prolactin has been reported as a possible reason for normoprolactinemic galactorrhea ${ }^{[30,31]}$ thus, it may be worth doing more than one prolactin level in a patient with unclear etiology of galactorrhea. Besides transient hyperprolactinemia, increased sensitivity of breast receptors to prolactin ${ }^{[29]}$ may be responsible for the galactorrhea. In the presence of normal regulation of prolactin secretion, prolactin concentration and bioactivity with normal ovarian cyclic function, idiopathic galactorrhea may develop from an increase sensitivity of breast tissue to prolactin. ${ }^{[32]}$ 
Table 1. Etiology of Galactorrhea ${ }^{[1,2,6-8,14,20,26,27,41]}$

\begin{tabular}{|c|c|}
\hline Physiologic & Pregnancy, postpartum period, lactation, stress, nipple/ breast manipulation \\
\hline Tumors & $\begin{array}{l}\text { Prolactinoma, craniopharyngiomas, germinoma, meningioma, broncho-genic carcinoma, renal } \\
\text { adeno-carcinoma, Hodgkin's and T-cell lymphomas }\end{array}$ \\
\hline Infiltrative diseases & Histiocytosis, sarcoidosis \\
\hline Diseases & $\begin{array}{l}\text { Hypothyroidism, chronic renal failure, Rathke’s cleft cysts, pituitary stalk inhibition, acromegaly, } \\
\text { multiple sclerosis, traumatic brain injury, subdural hematoma, glucocorticoid resistance syndrome }\end{array}$ \\
\hline \multicolumn{2}{|l|}{ Drugs } \\
\hline Histamine H2- receptor blockers & Cimetidine, famotidine, ranitidine \\
\hline Proton pump inhibitors & Lanzoprazole \\
\hline Antiemetics & Domperidone, metoclopramide, phenothiazines \\
\hline Antihypertensives & Atenolol, methyldopa, reserpine, verapamil \\
\hline Antidepressants and anxiolytics & Alprazolam, buspirone, moclobemide, amitriptyline, amoxapine \\
\hline Antipsychotics & Chlorpromazine, prochlorperazine, haloperidol, ziprasidone \\
\hline Selective serotonin reuptake inhibitors & Citalopram, fluoxetine, paroxetine, sertraline, fluvoxamine, escitalopram \\
\hline Hormones & $\begin{array}{l}\text { Conjugated estrogen, medroxy-progesterone, oral contraceptives (combination estrogen/ } \\
\text { progestin), octreotide, }\end{array}$ \\
\hline Other drugs & $\begin{array}{l}\text { Amphetamines, anaesthetics, arginine, cannabis, cisapride, danazol, dihydroergotamine, isoniazid, } \\
\text { opiates, sumatriptan, valproic acid }\end{array}$ \\
\hline Herbal medication & Red clover, blessed thistle, fennel, fenugreek seed \\
\hline Infection & Tuberculosis, schistosomiasis \\
\hline Dermatologic & $\begin{array}{l}\text { Atopic dermatitis, burns to chest with keloid formation, chest wall irritation, herpes zoster of upper } \\
\text { thorax }\end{array}$ \\
\hline Chest wall surgery & $\begin{array}{l}\text { Thoracotomy incisions, mastectomy, chest trauma with laceration, removal of breast tattoos, breast } \\
\text { reduction/ breast augmentation surgery }\end{array}$ \\
\hline Others: & Spinal cord injury \\
\hline
\end{tabular}

Table 2. Etiologies of Normoprolactinemic Galactorrhea

\begin{tabular}{|c|c|}
\hline Idiopathic & \\
\hline Neurologic & $\begin{array}{l}\text { Intracranial hypotension }^{[8]} \text {, empty sella }{ }^{[10]} \text {, pituitary } \\
\text { TSH secreting tumor }^{[11]} \text {, Cushing's disease }{ }^{[12]}\end{array}$ \\
\hline Endocrine & Obesity with eczema $^{[13]}$, hypothyroid ${ }^{[14]}$ \\
\hline \multirow{3}{*}{ Drugs } & GI: rabeprazole, domperidone ${ }^{[14,15]}$ \\
\hline & $\begin{array}{l}\text { Psychiatric: duloxetine }{ }^{[16]} \text {, paroxetine }{ }^{[17]} \text {. } \\
\text { quetiapine }{ }^{[18,19]} \text {, venlafaxine }{ }^{[20]} \text {, risperidone- } \\
\text { fluvoxamine combination }{ }^{[21]} \text {, ziprasidone }{ }^{[22]} \text {, } \\
\text { escitalopram }^{[23]} \text {, imipramine and escitalopram }{ }^{[24]}\end{array}$ \\
\hline & $\begin{array}{l}\text { Hormones: oral contraceptives }{ }^{[25]} \text {, depot medroxy- } \\
\text { progesterone acetate }{ }^{[26]}\end{array}$ \\
\hline Miscellaneous & $\begin{array}{l}\text { chest wall surgery }{ }^{[27]} \text {, breast reduction surgery }{ }^{[6]} \text {, } \\
\text { copper containing IUD }{ }^{[28]}\end{array}$ \\
\hline
\end{tabular}

Hypothalamic pituitary gonadal axis may also play an important role in the development of normoprolactinemic galactorrhea. Decrease in basal gonadotropin levels, lack of episodic secretion of $\mathrm{LH}^{[33]}$ or blunted response of gonadotropins (FSH and $\mathrm{LH}$ ) to gonadotropin releasing hormone $(\mathrm{GnRH})^{[34]}$ may contribute to the development of galactorrhea in normoprolactinemic patients. GnRH and thyrotropin-releasing hormone (TRH) may participate in induction of transient hyperprolactinemia. ${ }^{[31]}$ Additionally, TRH seems to have a role in developing galactorrhea in subclinical hypothyroid patients due to its influence on prolactin secretion. ${ }^{[35]}$
Other reported mechanisms for normoprolactinemic galactorrhea includes an increase secretion of growth hormone. ${ }^{[36]}$ Growth hormone has been reported to have lactogenic effects separate from those of prolactin. ${ }^{[37]}$ Hyperresponsiveness of 5-hydroxytryptamine type 1A (5HT1A) serotonin receptor $^{[38]}$ has also been associated with normoprolactinemic galactorrhea. Serotonin receptors play a role in regulation of neurotransmitter release including dopamine (prolactin inhibiting factor) and serotonin is an indirect modulator of prolactin secretion. ${ }^{[18]}$ The last, but not the least, important mechanism affecting hypothalamic dopamine secretion, prolactin secretion and probably prolactin function is the change in intracranial pressure. Based on the development of hyperprolactinemia and galactorrhea seen in traumatic brain hemorrhage, ${ }^{[7]}$ spontaneous intracranial hypotension ${ }^{[18]}$ and in normoprolactinemic galactorrhea with primary low cerebrospinal fluid pressure syndrome, ${ }^{[9]}$ we may speculate that the change in the intracranial pressure can lead to mechanical or biochemical cascade that can cause hypothalamic or pituitary inflammation or irritation which may affect prolactin secretion or prolactin function.

\subsection{Treatment of normoprolactinemic galactorrhea}

Normoprolactinemic galactorrhea is usually a benign condition; however, it needs to be treated if associated with infertility and/or irregular menstrual cycle. Among infer- 
tile couples, almost one third to two third ( 28 - 63 percent) may have normal serum prolactin level despite reporting galactorrhea. ${ }^{[39,40]}$ Treating the underlying cause would be a reasonable approach; however, finding the underlying cause of galactorrhea is sometimes challenging. Short term low dose dopamine agonist (cabergoline $0.5 \mathrm{mg}$ once weekly) can improve troublesome galactorrhea in a few months. Cabergoline should then be tapered off after the improvement. ${ }^{[2]}$ Bromocriptine was also found useful to resume fertility in infertile women with normoprolactinemic galactorrhea; however, the combination of bromocriptine with clomiphene was reported to be more effective. ${ }^{[40]}$ Patients should also be advised to not keep checking the breast for persistence of galactorrhea because repeated milking of the breast can stimulate prolactin production and delay the resolution of galactorrhea. ${ }^{[2]}$

\section{Conclusion}

In conclusion, postneurosurgical intervention galactorrhea is a diagnosis of exclusion. Although the differential diag- nosis is extensive, common causes of galactorrhea should be investigated first. This case illustrates that the development of normoprolactinemic galactorrhea after surgical intervention for aneurysmal brain hemorrhage could be possibly from the hemorrhage or decompression after surgical intervention leading to intracranial hypotension or decrease in cerebrospinal fluid pressure. Clinicians should be aware of this phenomenon so extensive work up for evaluation can be delayed while observing patient for spontaneous resolution. Patients can also be given the assurance that normoprolactinemic galactorrhea is usually self-limiting and treatment can be reserved in cases when accompanying discomfort from the galactorrhea, infertility or menstrual irregularities are present.

\section{CONFlicts of InTEREST Disclosure}

The authors have declared no conflicts of interest.

\section{REFERENCES}

[1] Agarwal M, Das A, Singh SA. Hyperprolactinemia with normal serum prolactin: Its clinical significance. J Hum Reprod Sci. 2010 May; 3(2): 111-2. PMid:21209758. https://doi .org/10.4103/ 0974-1208.69334

[2] Huang W, Molitch ME. Evaluation and management of galactorrhea. Am Fam Physician. 2012 Jun 1; 85(11): 1073-80. Review. PMid:22962879.

[3] Benjamin F. Normal lactation and galactorrhea. Clin Obstet Gynecol. 1994 Dec; 37(4): 887-97. PMid:7842556. https://doi.org/10 .1097/00003081-199412000-00015

[4] Canfield CJ, Bates RW. Nonpuerperal galactorrhea. N Engl J Med. 1965 Oct 21; 273(17): 897-902. PMid:5890778. https ://doi.or g/10.1056/NEJM196510212731703

[5] Frantz AG, Kleinberg DL. Prolactin: evidence that it is separate from growth hormone in human blood. Science. 1970 Nov 13; 170(3959): 745-7. PMid:5529569. https://doi .org/10.1126/science.17 0.3959 .745

[6] Majdak-Paredes EJ, Shafighi M, During V, et al. An unusual case of galactorrhea in a postmenopausal woman complicating breast reduction. J Plast Reconstr Aesthet Surg. 2009 Apr; 62(4): 542-6. PMid:18023264. https://doi.org/10.1016/j.bjps . 2007.10 .019

[7] de Leo R, Petruk KC, Crockford P. Galactorrhea after prolonged traumatic coma: case report. Neurosurgery. 1981 Aug; 9(2): 1778. PMid:7196511. https://doi.org/10.1227/00006123-198 108000-00013

[8] Schievink WI, Nu-o M, Rozen TD, et al. Hyperprolactinemia due to spontaneous intracranial hypotension. J Neurosurg. 2015 May; 122(5): 1020-5. PMid:25380110. https://doi.org/10.3171/20 14.9. JNS132687

[9] Yamamoto M, Suehiro T, Nakata H, et al. Primary low cerebrospinal fluid pressure syndrome associated with galactorrhea. Intern Med.
1993 Mar; 32(3): 228-31. PMid:8329818. https://doi.org/10 .2169 /internalmedicine. 32.228

[10] Jones JR, de Hempel PA, Kemmann E, et al. Galactorrhea and amenorrhea in a patient with an empty sella. Obstet Gynecol. 1977 Jan; 49(1 suppl): 9-11. PMid:556644.

[11] Benoit R, Pearson-Murphy BE, Robert F, et al. Hyperthyroidism due to a pituitary TSH secreting tumour with amenorrhoea-galactorrhoea. Clin Endocrinol (Oxf). 1980 Jan; 12(1): 11-9. https://doi.org/ 10.1111/j.1365-2265.1980.tb03127.x

[12] Goldman M, Abrams G, Aiken R. Cushing's disease; with galactorrhea, amenorrhea, and normal prolactin levels. N Y State J Med. 1980 Sep; 80(10): 1621-2. PMid:6932602.

[13] Fernandez TF, Ashraf AP. An Unusual Case of Galactorrhea With Normal Serum Prolactin. Clin Pediatr (Phila). 2018 Feb; 57(2): 238 240. PMid:28056542. https://doi .org/10.1177/0009922816 685821

[14] Patrascu OM, Chopra D, Dwivedi S. Galactorrhoea: Report of Two Cases. Maedica (Buchar). 2015 Jun; 10(2): 136-139.

[15] Demir AM, Kuloglu Z, Berberoglu M, et al. Euprolactinemic galactorrhea secondary to domperidone treatment. J Pediatr Endocrinol Metab. 2015 Jul; 28(7-8): 955-6. PMid:25781524. https://doi . org/10.1515/jpem-2014-0118

[16] Demirci S, Unubol M, Demirci K. Galactorrhea with normal prolactin levels associated with duloxetine. J Clin Psychopharmacol. 2015 Jun; 35(3): 346-7. PMid:25756878. https : //doi .org/10.1 097/JCP. 0000000000000298

[17] Gulati P, Chavan BS, Das S. Paroxetine-induced galactorrhea. Indian J Psychiatry. 2014 Oct; 56(4): 393-4. PMid:25568484.

[18] Kwak WJ, Patel A, Haq F, et al. Antipsychotic-induced euprolactinemic galactorrhea in an adolescent girl: A case report. Prim Care Companion CNS Disord. 2012; 14(1). pii: PCC.11101239. 
[19] Mushtaq S, Khan S, Patel H. Quetiapine-induced galactorrhea with normal prolactin level in an adult female patient. Prim Care Companion CNS Disord. 2012; 14(2). pii: PCC.11101284.

[20] Warren MB. Venlafaxine-Associated Euprolactinemic Galactorrhea and Hypersexuality: A Case Report and Review of the Literature. J Clin Psychopharmacol. 2016 Aug; 36(4): 399-400. PMid:27219091. https://doi.org/10.1097/JCP.0000000000000514

[21] Pratheesh PJ, Praharaj SK, Srivastava A. Euprolactinemic gynecomastia and galactorrhea with risperidone-fluvoxamine combination. Psychopharmacol Bull. 2011; 44(1): 70-3. PMid:22506441.

[22] Kopecek M, Bares M, Mohr P. Ziprasidone-induced galactorrhea: a case report. Neuro Endocrinol Lett. 2005 Feb; 26(1): 69-70. PMid:15726024.

[23] Praharaj SK. Euprolactinemic galactorrhea with escitalopram. J Neuropsychiatry Clin Neurosci. 2014 Summer; 26(3): E25-6. PMid:25093774. https://doi.org/10.1176/appi.neuropsyc h. 13070147

[24] Mahasuar R, Majhi P, Ravan JR. Euprolactinemic galactorrhea associated with use of imipramine and escitalopram in a postmenopausal woman. Gen Hosp Psychiatry. 2010 May-Jun; 32(3): 341. e11-3.

[25] Holtz G. Galactorrhea in oral contraceptive users. J Reprod Med. 1982 Apr; 27(4): 210-2. PMid:7201522.

[26] Omar HA, Zakharia RM, Kanungo S, et al. Incidence of galactorrhea in young women using Depot-Medroxyprogesterone Acetate. Scientific World Journal. 2006 May 5; 6: 538-41. PMid:16680366. https://doi.org/10.1100/tsw.2006.106

[27] MacFarlane IA, Rosin MD. Galactorrhoea following surgical procedures to the chest wall: the role of prolactin. Postgrad Med J. 1980 Jan; 56(651): 23-5. PMid:7189882. https ://doi.org/10.1136/ pgmj.56.651.23

[28] Giampietro O, Ramacciotti C, Moggi G. Normoprolactinemic galactorrhea in a fertile woman with a copper intra-uterine device (copper IUD). Acta Obstet Gynecol Scand. 1984; 63(1): 23-5. PMid:6539040. https://doi.org/10.3109/00016348409156269

[29] Iannotta F, Rizzuto G, Colombo F, et al. Determination of prolactin secretion in idiopathic galactorrhea. Minerva Endocrinol. 1989 AprJun; 14(2): 119-23. PMid:2761495.

[30] Kapcala LP, Molitch ME, Arno J, et al. Twenty-four-hour prolactin secretory patterns in women with galactorrhea, normal menses, normal random prolacting levels and abnormal sellar tomograms. J Endocrinol Invest. 1984 Oct; 7(5): 455-60. PMid:6439770. https : //doi.org/10.1007/BF03348450

[31] Rudolf K, Kunkel S, Rudolf H. GnRH-TRH and arg-GnRH-TRH test in females with normoprolactinemic galactorrhea. Zentralbl Gynakol. 1987; 109(8): 510-6. PMid:3111129.
[32] Johnston DG, Haigh J, Prescott RW, et al. Prolactin secretion and biological activity in females with galactorrhoea and normal circulating prolactin concentrations at rest. Clin Endocrinol (Oxf). 1985 May; 22(5): 661-78. https://doi.org/10.1111/j.1365-2265. 1985.tb03003.x

[33] Boyd AE 3rd, Spare S, Bower B, et al. Neurogenic galactorrheaamenorrhea. J Clin Endocrinol Metab. 1978 Dec; 47(6): 1374-7. PMid:263659. https : //doi .org/10.1210/jcem-47-6-1374

[34] Salmerón de Diego J, Alonso Rodríguez C, Santos Reyero M, et al. Variations of the plasma levels of gonadotrophins (FSH and LH) and of its response to stimulation with gonadotrophin releasing hormone $(\mathrm{GnRH})$ with different plasma levels of prolactin (PRL) in women with the syndrome of galactorrhea-amenorrhea (author's transl). Med Clin (Barc). 1981 Feb 25; 76(4): 164-8.

[35] Takai T, Yamamoto K, Saito K, et al. Galactorrhea in subclinical hypothyroidism. Endocrinol Jpn. 1987 Aug; 34(4): 539-44. PMid:3119317. https://doi.org/10.1507/endocrj1954.34 .539

[36] Ochoa R, Mason M, Fonseca E, et al. Distribution of growth hormone isoforms in sera from women with normal ovarian function, galactorrhea, and normoprolactinemia. Fertil Steril. 1993 Aug; 60(2): 272-5. https ://doi.org/10.1016/S0015-0282 (16) 56096-8

[37] Katznelson L, Kleinberg D, Vance ML, et al. Hypogonadism in patients with acromegaly: data from the multi-centre acromegaly registry pilot study. Clin Endocrinol (Oxf). 2001 Nov; 55(5): 699.

[38] Abdel Gadir A, Khatim MS, Muharib NS, et al. The aetiology of galactorrhoea in women with regular menstruation and normal prolactin levels. Hum Reprod. 1992 Aug; 7(7): 912-4. PMid:1430126. https://doi.org/10.1093/oxfordjournals .humrep.a137768

[39] Ugwa EA, Ashimi AO, Abubakar MY, et al. An assessment of serum prolactin levels among infertile women with galactorrhea attending a gynecological clinic North-West Nigeria. Niger Med J. 2016 MayJun; 57(3): 178-81. PMid:27397959. https://doi.org/10.410 3/0300-1652.184068

[40] Xue T, Li SW, Wang Y. Effectiveness of bromocriptine monotherapy or combination treatment with clomiphene for infertility in women with galactorrhea and normal prolactin: A systematic review and meta-analysis. Curr Ther Res Clin Exp. 2010 Aug; 71(4): 199-210. PMid:24688144. https://doi.org/10.1016/j.curtheres. 20 10.08 .001

[41] Pena KS, Rosenfeld JA. Evaluation and Treatment of Galactorrhoea. Am Fam Physician. 2001 May 1; 63(9): 1763-70. PMid:11352287. 